\title{
ANALIZA LASTNOSTI ZUNANJOSTI PRI PRVESNICAH CIKASTEGA GOVEDA ${ }^{1}$
}

\author{
Mojca SIMČIČ $\check{2}^{2,3}$, Miran ŠTEPEC ${ }^{2}$, Betka LOGAR ${ }^{4}$, Klemen POTOČNIK², Dušan TERČIČ2 \\ Delo je prispelo 12. decembra 2016, sprejeto 28. decembra 2016. \\ Received December 12, 2016; accepted December 28, 2016.
}

\begin{abstract}
Analiza lastnosti zunanjosti pri prvesnicah cikastega goveda
Cilj raziskave je bila analiza lastnosti zunanjosti pri 1.086 prvesnicah cikastega goveda. Statistični model smo analizirali s proceduro GLM v statističnem paketu SAS/STAT, ki je vključeval sistematski vpliv leta ocenjevanja ter starost živali ob ocenjevanju in čas po telitvi kot linearni regresiji. Prvesnice so bile $\mathrm{v}$ povprečju v vihru visoke $126,5 \mathrm{~cm}$ pri starosti 33,9 mesecev, kar nedvoumno kaže, da spada cika med pasme z manjšim do srednje velikim telesnim okvirom. Največji delež variabilnosti za lastnosti zunanjosti smo s statističnim modelom pojasnili pri merjenih lastnostih telesnega okvira $(0,14-0,17)$. Delež pojasnjene variabilnosti je bil pri posameznih lastnostih za avtohtonost med 0,03 in 0,07, pri sestavljeni lastnosti za avtohtonost pa 0,12 . Ugotovili smo, da na lastnosti zunanjosti in posledično na razvrstitev živali v tip pomembno vplivajo najmanj naslednji dejavniki: leto ocenjevanja, starost in stadij laktacije. Razvrstitev živali v ustrezen tip bi bilo zaradi tega potrebno opraviti po izvrednotenju ocen za lastnosti zunanjosti in izključitvi vplivov okolja. S tem bi dobili bolj pravilne razvrstitve živali v tip.

Ključne besede: govedo; avtohtone pasme; cikasto govedo; prvesnice; lastnosti zunanjosti; ocenjevanje; Slovenija
\end{abstract}

\section{UVOD}

Cikasto govedo ima tipičen in značilen barvni vzorec ter barvo plašča, ki se zelo razlikuje od drugih pasem goveda v Sloveniji. Osnovna barva plašča je rumenordeča do temno rdečerjava, največkrat kostanjevo rjava, ki mora prevladovati nad belo barvo. Glava mora biti osnovne barve. Po hrbtu imajo živali širši ali ožji bel pas, ki se nadaljuje

\section{Analysis of type traits of Cika first calving cows}

The aim of the study was to analyse type traits in 1,086 first-calving Cika cows. Statistical model was analysed by GLM procedure in SAS/STAT statistical package, which included the fixed effect of scoring year, and age at scoring and days after calving as linear regressions. First-calving cows were on average $126.5 \mathrm{~cm}$ high at the withers at the age of 33.9 months, which clearly shows that it belongs to small to medium body sized cattle. The largest proportion of the variability was explained in the measured traits of the body frame (0.14-0.17). The explained proportion of variability among individual traits of autochthonous was between 0.03 and 0.07 , while 0.12 in the composite trait of autochthonous. We found out that type traits and therefore the classification of animals were significantly affected at least the following effects: the scoring year, age and stage of lactation. Classification of animals into the appropriate type, should therefore, be carried out after exclusion of the environmental effects. This would give a more accurate classification of Cika first-calving cows.

Key words: cattle; autochthonous breeds; Cika cattle; first calving cows; type traits; scoring; Slovenia

pod repom do vimena ali mod in po trebuhu naprej do prsi. Rep je bele barve. Ožji ali širši beli pasovi so prisotni tudi čez zgornji del prednjih nog (v predelu komolčnega sklepa) in zadnjih nog (v predelu kolenskega sklepa). Barva vseh sluznic je rožnata. Barva rogov ob korenu je belorumena, na gornji tretjini rjavkasta, konice pa so svetlejše. Parklji so temne barve (Navodila za presojo ..., 1935; Žan Lotrič in sod., 2010).

1 Prispevek je del doktorske disertacije Mojce Simčič z naslovom »Fenotipske in genetske značilnosti cikastega goveda«, mentor prof. dr. Dragomir Kompan in somentor doc. dr. Gregor Gorjanc / This article is part of a doctoral dissertation entitled »Phenotypic and genetic characterisation of Cika cattle«, issued by Mojca Simčič, supervisor Assoc. Prof. Dragomir Kompan, Ph. D. and co-supervisor Assist. Prof. Gregor Gorjanc, Ph. D.

2 Univerza v Ljubljani, Biotehniška fakulteta, Oddelek za zootehniko, Groblje 3, SI-1230 Domžale, Slovenija

3 Korespondenčni avtor, e-naslov: mojca.simcic@bf.uni-lj.si

4 Kmetijski inštitut Slovenije, Hacquetova ulica 17, SI-1000 Ljubljana, Slovenija 
Cikasto govedo je slovenska avtohtona kombinirana pasma s poudarkom na prireji mleka, kljub temu se večina krav redi kot krave dojilje za prirejo odstavljenih telet. Rejski cilj je ohranjanje pasme v prvotnem tipu in preprečevanje parjenja v sorodstvu (Žan Lotrič in sod., 2010). V letu 2015 je bilo na podlagi 27 laktacijskih zaključkov ugotovljeno, da so krave cikastega goveda v standardni laktaciji priredile v povprečju $2.906 \mathrm{~kg}$ mleka s 3,55 \% mlečne maščobe in 3,19 \% mlečnih beljakovin (Sadar in sod., 2016).

Rejski program (Žan Lotrič in sod., 2010) določa, da se v ocenjevanje zunanjosti vključi vse prvesnice in krave, ki niso bile ocenjene kot prvesnice. Starost prvesnice na dan ocenjevanja je omejena na najmanj 560 dni tako, da se iz ocenjevanja po prvi telitvi izloči vse prvesnice, ki so telile premlade. Prvesnice, ki so telile mlajše od 560 dni, se oceni po drugi zaporedni telitvi. Največja starost prvesnice oz. krave na dan ocenjevanja ni omejena. Čas ocenjevanja je prilagojen tehnologiji reje, zato se živali ocenjuje izven pašne sezone. Po rejskem programu je predvideno ocenjevanje prvesnic od 15 do 120 dne po telitvi, kar velikokrat ni mogoče zaradi paše. Velikost populacije cikastega goveda je $\mathrm{v}$ primerjavi z ostalimi pasmami v Sloveniji majhna, zato vse plemenske živali ocenjuje samo en ocenjevalec.

Selekcija cikastega goveda temelji na lastnostih zunanjosti. Leta 2005 je bil sprejet in potrjen rejski program (Žan in sod., 2005). Ocenjevanje poteka na podlagi obrazca, ki je bil v letu 2006 posebej prirejen za cikasto govedo. Ocenjujejo se potencialni plemenski biki in vse prvesnice. Ocenjevanje lastnosti zunanjosti vključuje merjene in ocenjevane lastnosti. Lastnosti in način ocenjevanja pri potencialnih plemenskih bikih so podrobneje opisali Simčič in sod. (2015b). Posebnost ocenjevanja v primerjavi $z$ drugimi pasmami je dvanajst tako imenovanih posameznih lastnosti za avtohtonost, ki opisujejo pasemske značilnosti. Na podlagi posameznih ocen za avtohtonost, ocene za izraženost skočnega sklepa in višine vihra se vse živali neposredno na koncu ocenjevanja razvrsti v enega od treh tipov (cikasti, delni cikasti, pincgavski). Na podlagi skupne ocene za avtohtonost se izmed prvesnic, ki so bile razvrščene v cikasti tip, odberejo bikovske matere (Žan Lotrič in sod., 2010).

Preglednica 1: Število prvesnic cikastega goveda, vključenih v analizo lastnosti zunanjosti

Table 1: Number of Cika cattle first calving cows included in the analysis of type traits

\begin{tabular}{llrrr}
\hline & $\mathrm{n}$ & Povprečje \pm SD & Min & Max \\
\hline Starost (dni) & 1086 & $1033,0 \pm 161,2$ & 628 & 1460 \\
$\begin{array}{l}\text { Število dni po } \\
\text { telitvi (dni) }\end{array}$ & 1086 & $230,0 \pm 109,6$ & 2 & 446 \\
\hline
\end{tabular}

n - število živali, SD - standardni odklon, Min - najmanjša vrednost, Max - največja vrednost
Namen te raziskave je bila analiza lastnosti zunanjosti pri prvesnicah cikastega goveda, ki je osnova za oceno genetskih parametrov, ki so potrebni za napovedovanje plemenskih vrednosti.

\section{MATERIAL IN METODE}

\subsection{MATERIAL}

\subsubsection{PODATKI}

Podatke smo pridobili iz Centralne podatkovne zbirke (CPZ) Govedo (Logar in sod., 2005), ki jo vzdržujejo na Kmetijskem inštitutu Slovenije (KIS), ki je druga priznana organizacija v živinoreji. Pridobljeni podatki so bili zabeleženi v okviru ocenjevanja lastnosti zunanjosti v letih od 2006 do 2013.

\subsubsection{IZBOR PODATKOV}

V kolikor bi upoštevali določila rejskega programa glede ustrezne starosti prvesnice na dan ocenjevanja, bi v obdelavo zajeli 2.019 ženskih živali, kamor bi bile vključene tudi krave, saj največja starost ob ocenjevanju ni omejena. Predpostavili smo, da je ocenjevanje zunanjosti namenjeno prvesnicam, zato smo omejili starost ob ocenjevanju na največ 1.460 dni oziroma 4 leta, tako kot so priporočali de Haas in sod. (2007). Poleg tega smo izključili tudi vse krave, mlajše od štirih let, ki so bile ocenjene šele po drugi zaporedni telitvi. $V$ to skupino so spadale prvesnice, ki so telile mlajše od 560 dni, in krave, ki so bile iz različnih razlogov ocenjene šele po drugi telitvi. Prvesnic, ki so bile na dan ocenjevanja izven priporočenega stadija laktacije, nismo izključili iz nadaljnje analize. Vsem navedenim kontrolam je ustrezalo 1.086 prvesnic cikastega goveda, ki smo jih vključili v končno analizo (preglednica 1, preglednica 2).
Preglednica 2: Število ocenjenih prvesnic cikastega goveda po letih

Table 2: Number of scored first calving Cika cows in different years

\begin{tabular}{lc}
\hline Leto & Prvesnice \\
\hline 2006 & 99 \\
2007 & 101 \\
2008 & 146 \\
2009 & 137 \\
2010 & 153 \\
2011 & 154 \\
2012 & 177 \\
2013 & 119 \\
Skupaj & 1086 \\
\hline
\end{tabular}


Sistem ocenjevanja zunanjosti pri prvesnicah vključuje sklop merjenih lastnosti (4), sklop posameznih ocenjevanih lastnosti za avtohtonost (12), sklop posameznih ocenjevanih lastnosti za telesne oblike (6), sklop posameznih ocenjevanih lastnosti vimena (4) in sklop sestavljenih lastnosti (4). Istočasno se na podlagi izjave rejca ocenjuje še temperament in iztok mleka. Poleg tega se zabeležijo še odstopanja od želenih lastnosti zunanjosti kot napake. Ocenjevane napake v sklopu za avtohtonost so: temen gobec, neustrezna barva plašča, beli znaki na glavi, beli znaki na nogah, pikasto pisana barva plašča, prekinjena hrbtna lisa in hrbtna lisa na križu. Ocenjevane napake v sklopu za telesne oblike so: razplečenost, visoko nasajen rep, vdolbina med sednicama, kravja stoja in razprti parklji. Ocenjevane napake v sklopu za vime so: stopničasto vime, lijakasti seski in stran štrleči seski. Sestavljene lastnosti ocenjujejo avtohtonost (pasemske značilnosti), omišičenost, telesne oblike in vime. Merjene lastnosti so podane $\mathrm{v}$ centimetrih, ocenjevane pa na linearni lestvici z ocenami od 1 do 9. Lastnosti in način ocenjevanja so podrobneje opisani v rejskem programu (Žan Lotrič in sod., 2010) in v okviru analize lastnosti zunanjosti pri potencialnih plemenskih bikih cikastega goveda (Simčič in sod., 2015b).

Merjene lastnosti za velikost okvirja se merijo z Lydtinovo palico in $\mathrm{z}$ merilnim trakom. Posamezne lastnosti za avtohtonost, ki so pasemske značilnosti, se ocenjujejo $\mathrm{z}$ ocenami. Ocena 1 ne pomeni pri vseh lastnosti najmanj izražene lastnosti, kakor tudi ne pomeni ocena 9 najbolj izražene lastnosti, kot je poznano pri linearnem načinu ocenjevanja zunanjosti v skladu s pravili Mednarodnega komiteja za kontrolo proizvodnje živali - ICAR (International Committee for Animal Recording - ICAR [ICAR], 2016; Klopčič in Hamoen, 2010). V preglednici 4 je za vsako posamezno lastnost za avtohtonost navedeno, kaj pomenita ekstremni oceni 1 in 9. Posamezne lastnosti za telesne oblike ter posamezne lastnosti za vime se pri prvesnicah ocenjujejo v skladu s pravili ICAR (ICAR, 2016).
Sestavljena ocena za avtohtonost se oceni z upoštevanjem optimalnih vrednosti nekaterih posameznih lastnosti za avtohtonost, za izraženost skočnega sklepa ter za višino vihra (preglednica 3), kot je navedeno v rejskem programu (Žan Lotrič in sod., 2010). Sestavljeno oceno za omišičenost predstavlja predvsem ocena zunanje linije stegna pri pogledu od zadaj. Sestavljena ocena za telesne oblike se oceni na podlagi posameznih lastnosti za telesne oblike in z upoštevanjem napak, zabeleženih v tem sklopu. Sestavljena ocena za vime se oceni na podlagi posameznih lastnosti za vime in $\mathrm{z}$ upoštevanjem napak, zabeleženih v tem sklopu.

\subsection{METODE}

Za analizo variance lastnosti zunanjosti pri prvesnicah smo uporabili proceduro GLM iz statističnega paketa SAS/STAT (SAS Institute Inc., 2001). V model 1 so bili vključeni:

$y_{i j k}=\mu+L_{i}+b_{I}\left(x_{i j k}-\bar{x}\right)+b_{I I}\left(z_{i j k}-\bar{z}\right)+e_{i j k}$

$y_{i j k}$ je lastnost zunanjosti, $\mu$ je povprečje populacije, $L_{i}$ je sistematski vpliv leta ocenjevanja $(i=1, \ldots, 9), b_{I}$ je linearni regresijski koeficient za starost na dan ocenjevanja, $x_{i j k}$ je starost na dan ocenjevanja (dnevi), $b_{I I}$ je linearni regresijski koeficient za čas po telitvi, $z_{i j k}$ je čas po telitvi na dan ocenjevanja (dnevi) in $e_{i j k}$ je naključni ostanek.

\section{REZULTATI IN DISKUSIJA}

Pričujoča raziskava je prva podrobna analiza lastnosti zunanjosti prvesnic v populaciji cikastega goveda. Prvesnic za namen analize variance lastnosti zunanjosti nismo

Preglednica 3: Optimalne vrednosti ocen za lastnosti, ki se upoštevajo v sestavljeni oceni za avtohtonost pri prvesnicah Table 3: Optimal scores for traits which are included in the composite trait for autochthonous in first calving cows

\begin{tabular}{lll}
\hline Sklop & Lastnost & Optimalna vrednost \\
\hline Lastnosti za avtohtonost & Dolžina glave & $6-8$ \\
& Izraženost oči & $6-8$ \\
& Debelina rogov & $6-8$ \\
& Dolžina rogov & $6-9$ \\
& Usmerjenost rogov & $6-9$ \\
\hline Lastnosti za telesne oblike & Vrat & $7-9$ \\
\hline Merjene lastnosti telesnega okvira & Izraženost podgrline & $6-9$ \\
\hline
\end{tabular}


razvrstili glede na tip, temveč smo zajeli celotno populacijo, ne glede na tip.

Cikasto govedo je zgodaj zrela pasma, zato so telice sposobne za oploditev že zelo zgodaj, pri starosti 10 mesecev ali celo manj. Do prezgodnjih oploditev in posledično do prezgodnjih telitev pride največkrat na kmetijah, kjer imajo $v$ čredi na paši plemenskega bika za naravni pripust. $\mathrm{V}$ takih primerih je v rejskem programu določeno, da se prvesnice, ki so telile mlajše od $560 \mathrm{dni}$, oceni šele po drugi telitvi. Podobno kot pri cikah se z zgodnjimi telitvami srečujejo tudi pri drugih pasmah (de Haas in sod., 2007), vendar ocenijo tudi take prvesnice po prvi telitvi. Na ta način izključimo sistematski vpliv zaporedne telitve na lastnosti zunanjosti, do česar prihaja po sedaj veljavnih priporočilih pri cikah.

V Švici (de Haas in sod., 2007) prvesnice holštajnskega, ameriškega rjavega in rdečega holštajnskega goveda telijo pri starosti od 500 do 1.460 dni in jih ocenijo pri starosti od 500 do $1.825 \mathrm{dni}$. Za primerjavo lahko navedemo, da se prvesnice rjavega goveda v Sloveniji ocenjuje pri starosti od 505 do 1.565 dni (Špehar in sod., 2012), prvesnice češkega holštajnskega goveda pri starosti 660 do 960 dni (Němcová in sod., 2011) in prvesnice piemontese goveda pri starosti 670 do 1.160 dni (Mantovani in sod., 2010). Pri chianina govedu v Italiji pa so v ocenjevanje zunanjosti vključene tako prvesnice kot tudi krave po drugi zaporedni telitvi in vpliva zaporedne telitve ne upoštevajo (Forabosco in sod., 2004).

Za prvesnice cikastega goveda je $\mathrm{v}$ rejskem programu določeno, da se jih oceni 15. do 120. dan po telitvi, kar je v skladu z Navodili ICAR (ICAR, 2016), ki tudi priporoča, da presušenih krav ne vključimo v ocenjevanje. Čas štirih mesecev po telitvi je zelo kratek, zato npr. prvesnice češkega holštajnskega goveda ocenjujejo med 30. in 210. dnem po telitvi (Němcová in sod., 2011). Vse plemenske živali cikastega goveda v Sloveniji ocenjuje samo en ocenjevalec, saj ICAR priporoča, da naj bi vsak ocenjevalec v enem letu ocenil vsaj 200 živali določene pasme. Poleg tega isti ocenjevalec ocenjuje tudi prvesnice drugih pasem.

\subsection{OPISNA STATISTIKA}

Opisna statistika za prvesnice je prikazana (preglednica 4) skupaj z opisi lastnosti. Srednje vrednosti za merjene lastnosti telesnega okvira so bile $126,49 \pm 5,51 \mathrm{~cm}$ za višino vihra, $129,89 \pm 5,56 \mathrm{~cm}$ za višino križa, $127,65 \pm 6,13 \mathrm{~cm}$ za dolžino telesa in $174,64 \pm 9,80 \mathrm{~cm}$ za obseg prsi. Koeficient variabilnosti za merjene lastnosti je bil od 4,28 \% do $5,61 \%$, za sestavljene lastnosti za avtohtonost 30,38 \%, za omišičenost $20,32 \%$, za telesne oblike $20,20 \%$ in za vime $22,67 \%$. Pri analiziranju ocen smo opazili zelo majhno zastopanost obeh ekstremnih ocen na lestvici, 1 oziroma 9.
Pri ocenjevanih lastnostih zunanjosti pri prvesnicah piemontese goveda na lestvici od 1 do 9 so bili izračunani koeficienti variabilnosti od 0,12-0,26 (Mantovani, 2010). Primerjava ocenjevanih lastnosti zunanjosti cikastega goveda $\mathrm{z}$ drugimi pasmami je bila mogoča samo $\mathrm{v}$ primerih, ko se je uporabljala enaka lestvica za ocenjevanje. Pri ocenjevanju zunanjosti italijanskih avtohtonih pasem goveda rendena, valdostana in chianina uporabljajo lestvico od 1 do 5 (Mazza in sod., 2013; Mazza in sod., 2014, Forabosco in sod., 2004), pri piemontese govedu pa 1-9 (Mantovani in sod., 2010). Za ocenjevanje zunanjosti prvesnic asturiana de los valles goveda so razvili poseben sistem $\mathrm{z}$ lestvico od 1 do 9 , s katerim ocenijo razvitost skeleta in omišičenost ter pasemske značilnosti (Gutiérrez in Goyache, 2002). Do razlik med pasmami prihaja tudi zaradi različnih definicij lastnosti z istim imenom.

Němcová in sod. (2011) ter Špehar in sod. (2012) so na osnovi ocen na linearni lestvici od 1 do 9 , v skladu s pravili ICAR (ICAR, 2016), analizirali lastnosti zunanjosti pri prvesnicah češkega holštajnskega in rjavega goveda. Srednje vrednosti za posamezne lastnosti zunanjosti pri prvesnicah holštajnskega $(4,9-5,9)$ in rjavega goveda $(4,73-5,86)$ so bile podobne srednjim vrednostim posameznih ocenjevanih lastnosti zunanjosti pri prvesnicah cikastega goveda $(4,73-6,25)$.

Srednja vrednost za višino vihra pri prvesnicah cikastega goveda $(126,49 \pm 5,51 \mathrm{~cm})$ nedvoumno kaže, da spada cika med pasme $\mathrm{z}$ manjšim do srednje velikim telesnim okvirom, saj je $\mathrm{v}$ vihru manjša $\mathrm{v}$ primerjavi s prvesnicami holštajnskega $(143 \mathrm{~cm})$, ameriškega rjavega $(139 \mathrm{~cm})$ in rdečega holštajnskega goveda $(142 \mathrm{~cm}$ ) (de Haas in sod., 2007) ter prvesnicami piemontese goveda $(130,81 \pm 3,64$ $\mathrm{cm}$ ) iz Italije (Mantovani in sod., 2010). V križu so bile prvesnice cikastega goveda visoke 129,89 cm, kar je manj od prvesnic rjavega goveda $(139,8 \mathrm{~cm})$ v Sloveniji (Špehar in sod., 2012).

V preglednici 5 so predstavljene vrednosti sestavljene ocene za avtohtonost in opis zunanjosti ločeno za prvesnice, porazdeljene glede na posamezen tip (cikasti, delni cikasti, pincgavski). Razvrščanje živali v ustrezen tip se izvede ob koncu ocenjevanja vsake posamezne živali.

Pri ocenjevanju sestavljene lastnosti za avtohtonost se, poleg posameznih ocen $\mathrm{v}$ sklopu za avtohtonost in zabeleženih napak, upoštevajo tudi »Navodila za presojo barvnih znakov cikastega goveda", ki so bila objavljena leta 1935 v Službenem listu kraljevske banske uprave dravske banovine kot Banova uredba. Bistvene napake, opisane v navodilih, ki žival »izključujejo«, so črna ali presvetla (žemljasta ali rumenkasta) barva plašča, očitna pomešanost osnovne rjave barve $\mathrm{z}$ belo barvo, beli znaki na glavi in na nogah (Navodila za presojo..., 1935).

$\mathrm{V}$ preglednici 6 so deleži prvesnic $\mathrm{z}$ napakami lastnosti zunanjosti. Največ prvesnic (18,78 \%) je imelo prekinje- 
Preglednica 4: Opisna statistika za lastnosti zunanjosti pri prvesnicah cikastega goveda Table 4: Descriptive statistics for type traits in Cika cattle first calving cows

\begin{tabular}{|c|c|c|c|c|c|c|c|}
\hline Lastnosti & $\mathrm{n}$ & Povprečje \pm SD & Min & Max & KV (\%) & $\begin{array}{l}\text { Optimalna } \\
\text { vrednost }\end{array}$ & Opis ocen $1-9$ \\
\hline Starost (meseci) & 1086 & $33,88 \pm 5,29$ & 21,0 & 48,0 & 15,61 & & \\
\hline \multicolumn{8}{|l|}{ Merjene lastnosti za telesni okvir } \\
\hline Višina vihra $(\mathrm{cm})$ & 1086 & $126,49 \pm 5,51$ & 112 & 142 & 4,35 & $\leq 125 \mathrm{~cm}$ & \\
\hline Višina križa (cm) & 1086 & $129,89 \pm 5,56$ & 114 & 146 & 4,28 & & \\
\hline Dolžina telesa $(\mathrm{cm})$ & 1086 & $127,65 \pm 6,13$ & 105 & 146 & 4,81 & & \\
\hline Obseg prsi $(\mathrm{cm})$ & 1086 & $174,64 \pm 9,80$ & 150 & 203 & 5,61 & & \\
\hline \multicolumn{8}{|c|}{ Posamezne lastnosti za avtohtonost (1-9) } \\
\hline Dolžina glave & 1086 & $5,23 \pm 1,31$ & 2 & 9 & 25,13 & $6-8$ & dolga - kratka \\
\hline Plemenitost glave & 450 & $5,45 \pm 1,27$ & 2 & 9 & 23,33 & & groba - plemenita \\
\hline Izraženost oči & 1086 & $5,59 \pm 1,02$ & 2 & 9 & 18,28 & $6-8$ & slaba - močna \\
\hline Debelina rogov & 1064 & $4,73 \pm 1,37$ & 1 & 9 & 28,97 & $6-8$ & debeli - tanki \\
\hline Dolžina rogov & 869 & $5,08 \pm 1,25$ & 2 & 9 & 24,64 & $6-9$ & dolgi - kratki \\
\hline Usmerjenost rogov & 1064 & $5,15 \pm 1,59$ & 2 & 9 & 30,90 & $6-9$ & navzven - naprej \\
\hline Vrat & 1086 & $5,17 \pm 1,36$ & 2 & 9 & 26,33 & $7-9$ & grob - plemenit \\
\hline Izraženost podgrline & 1086 & $4,93 \pm 1,33$ & 2 & 9 & 26,91 & $6-9$ & močna - slaba \\
\hline Barva plašča & 1086 & $5,10 \pm 1,37$ & 1 & 9 & 26,87 & & zelo temna - zelo svetla \\
\hline Izraženost hrbtne lise & 1086 & $5,17 \pm 1,53$ & 1 & 9 & 29,62 & & močna - slaba \\
\hline Izraženost pasov na zadnjih nogah & 1086 & $5,40 \pm 1,87$ & 1 & 9 & 34,62 & & močna - slaba \\
\hline Izraženost pasov na prednjih nogah & 1086 & $6,25 \pm 1,75$ & 1 & 9 & 27,93 & & močna - slaba \\
\hline \multicolumn{8}{|c|}{ Posamezne lastnosti za telesne oblike (1-9) } \\
\hline Hrbet & 1086 & $4,73 \pm 0,60$ & 2 & 7 & 12,66 & $4-6$ & uleknjen - izbočen \\
\hline Nagib križa & 1086 & $5,18 \pm 0,79$ & 2 & 8 & 15,25 & $4-6$ & nadgrajen - pobit \\
\hline Kot skočnega sklepa & 1086 & $5,54 \pm 0,80$ & 3 & 8 & 14,38 & $4-6$ & strm - sabljast \\
\hline Izraženost skočnega sklepa & 1086 & $5,56 \pm 1,29$ & 2 & 9 & 23,26 & $6-9$ & zadebeljen - tanek \\
\hline Biclji & 1086 & $5,89 \pm 0,95$ & 3 & 8 & 16,14 & $6-8$ & mehki - strmi \\
\hline Parklji & 1086 & $5,73 \pm 0,96$ & 2 & 9 & 16,67 & $6-9$ & nizki - visoki \\
\hline \multicolumn{8}{|l|}{ Posamezne lastnosti za vime (1-9) } \\
\hline Vime pod trebuhom & 1086 & $4,90 \pm 1,06$ & 2 & 8 & 21,58 & $6-9$ & majhno - obsežno \\
\hline Globina vimena & 1086 & $5,39 \pm 1,04$ & 2 & 8 & 19,29 & $6-9$ & spuščeno - pripeto \\
\hline Debelina prednjih seskov & 1086 & $5,01 \pm 0,97$ & 2 & 8 & 19,30 & $4-6$ & tanki - debeli \\
\hline Dolžina prednjih seskov & 1086 & $5,36 \pm 1,06$ & 2 & 9 & 19,69 & $4-6$ & kratki - dolgi \\
\hline \multicolumn{8}{|l|}{ Izjava rejca $(1-5)$} \\
\hline Iztok mleka & 1082 & $3,54 \pm 0,59$ & 1 & 5 & 16,51 & & počasen - hiter \\
\hline Temperament & 1082 & $3,75 \pm 0,76$ & 1 & 5 & 20,42 & & nervozen - miren \\
\hline \multicolumn{8}{|l|}{ Sestavljene lastnosti (1-9) } \\
\hline Avtohtonost & 1086 & $5,03 \pm 1,53$ & 1 & 9 & 30,38 & & \\
\hline Omišičenost & 1086 & $5,47 \pm 1,11$ & 2 & 9 & 20,32 & & \\
\hline Telesne oblike & 1086 & $5,67 \pm 1,14$ & 2 & 8 & 20,20 & & \\
\hline Vime & 1086 & $5,01 \pm 1,14$ & 1 & 8 & 22,67 & & \\
\hline
\end{tabular}

SD - standardni odklon, KV - koeficient variabilnosti 
Preglednica 5: Opis treh tipov cikastega goveda (Žan Lotrič in sod., 2010)

Table 5: Description of three types of Cika cattle (Žan Lotrič et al., 2010)

\begin{tabular}{lll}
\hline Tip & $\begin{array}{l}\text { Sestavljena ocena } \\
\text { za avtohtonost }\end{array}$ & Opis zunanjosti \\
\hline Cikasti tip & $7,8,9$ & $\begin{array}{l}\text { fina konstitucija, manǰ̌i okvir, kratka glava, širok gobec, izražene velike oči, tanki } \\
\text { in kratki rogovi usmerjeni naprej in navzgor, tanka nagubana koža na vratu, neiz- } \\
\text { razita podgrlina, tanke noge, obsežen vamp }\end{array}$ \\
\hline Delni cikasti tip & $4,5,6$ & $\begin{array}{l}\text { srednje velik telesni okvir, združuje lastnosti zunanjosti cikastega in pincgavskega } \\
\text { tipa, določene lastnosti zunanjosti so značilne za druge pasme (primesi) }\end{array}$ \\
\hline Pincgavski tip & $1,2,3$ & $\begin{array}{l}\text { večji okvir, dolga glava, ozek gobec, neizrazite majhne oči, debeli in navzven us- } \\
\text { merjeni rogovi, debela koža na vratu, obsežna podgrlina, debele noge, povit trup }\end{array}$ \\
\hline
\end{tabular}

no hrbtno liso, ki se upošteva kot napaka v sklopu avtohtonih lastnosti. V sklopu napak telesnih oblik je bil največji delež prvesnic $(18,14 \%)$ z visoko nasajenim repom. Napake vimena, zabeležene kot število paseskov, je imelo $27,35 \%$ prvesnic, stran štrleče seske pa je imelo 10,31 \% prvesnic. Vse druge zabeležene napake $\mathrm{v}$ vseh sklopih so bile prisotne pri manjšem deležu prvesnic $v$ populaciji.

V preglednici 7 so prikazane srednje vrednosti za lastnosti zunanjosti pri 1.086 prvesnicah, ki so bile razvrščene v cikasti tip (213), delni cikasti (681) in pincgavski tip

Preglednica 6: Delež živali z napakami pri lastnostih zunanjosti Table 6: The proportion of animals with defects of type traits

\begin{tabular}{llr}
\hline & \multicolumn{2}{l}{ Prvesnice $(\mathrm{n}=1.086)$} \\
\hline Napake v sklopu avtohtonost & $\mathrm{n}$ & \multicolumn{1}{c}{$\%$} \\
\hline Temen gobec & 55 & 1,06 \\
Neustrezna barva plašča & 44 & 4,05 \\
Beli znaki na glavi & 75 & 6,91 \\
Beli znaki na nogah & 55 & 5,06 \\
Pikasto pisana & 204 & 18,78 \\
Prekinjena hrbtna lisa & 72 & 6,63 \\
Hrbtna lisa na križu & & 4,05 \\
\hline Napake v sklopu telesne oblike & 44 & 18,14 \\
\hline Razplečenost & 197 & 0,46 \\
Visoko nasajen rep & 5 & 8,47 \\
Vdolbina med sednicama & 92 & 0,37 \\
Kravja stoja & 4 & 0,00 \\
Razprti parklji & & 4,14 \\
\hline Napake v sklopu vime & 45 & 2,95 \\
\hline Stopničasto vime & 32 & 10,31 \\
Lijakasti seski & 112 & 27,35 \\
Stran štrleči seski & 297 & 1,29 \\
Paseski & 5 & \\
Medseski & & \\
Priseski & & \\
\hline & & \\
\hline
\end{tabular}

(192). Med prvesnicami vseh treh tipov je bila tudi razlika $\mathrm{v}$ starosti, in sicer so bile prvesnice, razvrščene v cikasti tip, 1,3 meseca mlajše od prvesnic, razvrščenih $\mathrm{v}$ delni cikasti tip, in 2,9 meseca mlajše od prvesnic $\mathrm{v}$ pincgavskem tipu. Prvesnice v cikastem tipu so bile v povprečju v vihru in križu manjše od prvesnic $\mathrm{v}$ delnem cikastem tipu za 4,5 cm oz. $4,8 \mathrm{~cm}$ in $10,9 \mathrm{~cm}$ oz. $11,2 \mathrm{~cm}$ od prvesnic v pincgavskem tipu. Prav tako so imele prvesnice v cikastem tipu za $4,6 \mathrm{~cm}$ krajšo dolžino telesa od prvesnic v delnem cikastem tipu in za $10,4 \mathrm{~cm}$ od prvesnic $\mathrm{v}$ pincgavskem tipu. Prvesnice v cikastem tipu so imele $6,5 \mathrm{~cm}$ manjši obseg prsi od prvesnic v delnem cikastem tipu in 15,6 $\mathrm{cm}$ od prvesnic v pincgavskem tipu. Prav vse posamezne lastnosti za avtohtonost so bile v povprečju ocenjene kot bolj zaželene pri prvesnicah v cikastem tipu. Sestavljena lastnost za avtohtonost je bila za 2,2 ocene bolje ocenjena pri cikastem tipu $\mathrm{v}$ primerjavi $\mathrm{z}$ delnim cikastim tipom in za 4,5 ocene bolje $\mathrm{v}$ primerjavi s pincgavskim tipom prvesnic, kar pomeni, da so imele prvesnice, razvrščene $\mathrm{v}$ cikasti tip, najbolj izražene avtohtone lastnosti. Ocene za posamezne lastnosti za telesne oblike so bile zelo podobne pri vseh treh tipih prvesnic, $\mathrm{z}$ izjemo izraženosti skočnega sklepa, ki je bil pri cikastem tipu v povprečju ocenjen za 1,2 ocene bolje $\mathrm{v}$ primerjavi $\mathrm{z}$ delnim cikastim tipom in 2,5 ocene bolje $\mathrm{v}$ primerjavi s pincgavskim tipom prvesnic. Sestavljena lastnost za telesne oblike je bila za 0,7 ocene boljša pri cikastem tipu $\mathrm{v}$ primerjavi $\mathrm{z}$ delnim cikastim in za 0,9 ocene boljša v primerjavi s pincgavskim tipom prvesnic. Prvesnice v cikastem tipu so imele za 0,2 ocene slabšo omišičenost $\mathrm{v}$ primerjavi $\mathrm{z}$ delnim cikastim in za 0,8 ocene slabšo omišičenost $\mathrm{v}$ primerjavi s pincgavskim tipom prvesnic. Sestavljena lastnost za vime je bila za 0,8 ocene boljša pri cikastem tipu prvesnic $\mathrm{v}$ primerjavi $\mathrm{z}$ delnim cikastim in za 1 oceno boljša $\mathrm{v}$ primerjavi s pincgavskim tipom prvesnic.

Merjene lastnosti telesnega okvira sedanje populacije prvesnic cikastega goveda smo primerjali s populacijami, ki so bile v preteklosti razširjene na območju, ki ustreza današnji razširjenosti cikastega goveda in so imele po opisu podobno barvo plašča. Ugotovili smo, da so prvesnice 
Preglednica 7: Opisna statistika za lastnosti zunanjosti pri prvesnicah vseh treh tipov cikastega goveda Table 7: Descriptive statistics for type traits for all types of Cika cattle first calving cows

\begin{tabular}{|c|c|c|c|}
\hline $\begin{array}{l}\text { Lastnosti } \\
\text { (povprečje } \pm \text { SD) }\end{array}$ & $\begin{array}{l}\text { Cikasti tip } \\
(\mathrm{n}=213)\end{array}$ & $\begin{array}{l}\text { Delni cikasti tip } \\
(\mathrm{n}=681)\end{array}$ & $\begin{array}{l}\text { Pincgavski tip } \\
(\mathrm{n}=192)\end{array}$ \\
\hline Starost (meseci) & $32,61 \pm 5,12$ & $33,88 \pm 5,38$ & $35,29 \pm 4,80$ \\
\hline \multicolumn{4}{|l|}{ Merjene lastnosti za telesni okvir } \\
\hline Višina vihra $(\mathrm{cm})$ & $121,77 \pm 3,78$ & $126,22 \pm 4,64$ & $132,69 \pm 4,00$ \\
\hline Višina križa $(\mathrm{cm})$ & $124,92 \pm 3,92$ & $129,68 \pm 4,65$ & $136,12 \pm 3,82$ \\
\hline Dolžina telesa $(\mathrm{cm})$ & $122,94 \pm 4,67$ & $127,53 \pm 5,52$ & $133,29 \pm 4,91$ \\
\hline Obseg prsi $(\mathrm{cm})$ & $167,83 \pm 7,36$ & $174,30 \pm 8,81$ & $183,41 \pm 8,94$ \\
\hline \multicolumn{4}{|c|}{ Posamezne lastnosti za avtohtonost (1-9) } \\
\hline Dolžina glave & $6,18 \pm 1,10$ & $5,16 \pm 1,20$ & $4,44 \pm 1,28$ \\
\hline Plemenitost glave & $6,61 \pm 0,85$ & $5,25 \pm 1,05$ & $3,75 \pm 1,03$ \\
\hline Izraženost oči & $6,26 \pm 0,85$ & $5,53 \pm 0,96$ & $5,02 \pm 1,00$ \\
\hline Debelina rogov & $5,87 \pm 1,14$ & $4,65 \pm 1,22$ & $3,71 \pm 1,19$ \\
\hline Dolžina rogov & $5,68 \pm 1,14$ & $5,04 \pm 1,19$ & $4,30 \pm 1,27$ \\
\hline Usmerjenost rogov & $6,20 \pm 1,26$ & $5,08 \pm 1,49$ & $4,17 \pm 1,58$ \\
\hline Vrat & $6,53 \pm 0,84$ & $5,14 \pm 1,15$ & $3,80 \pm 1,06$ \\
\hline Izraženost podgrline & $6,02 \pm 1,08$ & $4,89 \pm 1,21$ & $3,87 \pm 1,04$ \\
\hline Pigmentacija plašča & $5,63 \pm 1,24$ & $5,06 \pm 1,37$ & $4,64 \pm 1,34$ \\
\hline Izraženost hrbtne lise & $5,48 \pm 1,41$ & $5,21 \pm 1,50$ & $4,68 \pm 1,66$ \\
\hline Izraženost pasov na zadnjih nogah & $5,83 \pm 1,72$ & $5,45 \pm 1,84$ & $4,76 \pm 1,98$ \\
\hline Izraženost pasov na prednjih nogah & $6,62 \pm 1,51$ & $6,29 \pm 1,73$ & $5,71 \pm 1,93$ \\
\hline \multicolumn{4}{|c|}{ Posamezne lastnosti za telesne oblike (1-9) } \\
\hline Hrbet & $4,74 \pm 0,55$ & $4,75 \pm 0,60$ & $4,68 \pm 0,64$ \\
\hline Nagib križa & $4,99 \pm 0,77$ & $5,20 \pm 0,77$ & $5,31 \pm 0,85$ \\
\hline Kot skočnega sklepa & $5,62 \pm 0,74$ & $5,53 \pm 0,80$ & $5,50 \pm 0,84$ \\
\hline Izraženost skočnega sklepa & $6,74 \pm 0,81$ & $5,57 \pm 1,09$ & $4,20 \pm 1,03$ \\
\hline Biclji & $5,94 \pm 0,80$ & $5,84 \pm 0,96$ & $6,01 \pm 1,07$ \\
\hline Parklji & $5,78 \pm 0,86$ & $5,70 \pm 0,93$ & $5,77 \pm 1,13$ \\
\hline \multicolumn{4}{|l|}{ Posamezne lastnosti za vime (1-9) } \\
\hline Vime pod trebuhom & $5,51 \pm 0,91$ & $4,80 \pm 1,04$ & $4,58 \pm 0,99$ \\
\hline Globina vimena & $5,86 \pm 0,92$ & $5,34 \pm 0,99$ & $5,07 \pm 1,17$ \\
\hline Debelina prednjih seskov & $4,71 \pm 0,88$ & $5,03 \pm 0,95$ & $5,29 \pm 1,04$ \\
\hline$\underline{\text { Dolžina prednjih seskov }}$ & $5,12 \pm 1,04$ & $5,40 \pm 1,04$ & $5,46 \pm 1,10$ \\
\hline \multicolumn{4}{|l|}{ Izjava rejca (1-5) } \\
\hline Iztok mleka & $3,82 \pm 0,56$ & $3,49 \pm 0,57$ & $3,43 \pm 0,58$ \\
\hline Temperament & $3,95 \pm 0,85$ & $3,71 \pm 0,74$ & $3,66 \pm 0,70$ \\
\hline \multicolumn{4}{|l|}{ Sestavljene lastnosti (1-9) } \\
\hline Avtohtonost & $7,19 \pm 0,41$ & $5,00 \pm 0,81$ & $2,72 \pm 0,47$ \\
\hline Omišičenost & $5,20 \pm 0,88$ & $5,41 \pm 1,10$ & $5,99 \pm 1,22$ \\
\hline Telesne oblike & $6,27 \pm 0,95$ & $5,58 \pm 1,11$ & $5,31 \pm 1,23$ \\
\hline Vime & $5,68 \pm 0,99$ & $4,90 \pm 1,09$ & $4,64 \pm 1,14$ \\
\hline
\end{tabular}

SD - standardni odklon 
sedanje populacije v cikastem tipu, ki naj bi predstavljal prvotni tip cikastega goveda, $\mathrm{v}$ vihru $(121,77 \pm 3,78 \mathrm{~cm})$ in križu $(124,92 \pm 3,92 \mathrm{~cm})$ višje od krav bohinjskega $(118 \mathrm{~cm} ; 116 \mathrm{~cm})$ in rdeče-pisanega gorenjskega goveda $(118 \mathrm{~cm} ; 120 \mathrm{~cm})$ (Povše, 1893) ter višje od krav bovškega $(119 \mathrm{~cm} ; 118 \mathrm{~cm})$ in tolminskega goveda $(120 \mathrm{~cm} ; 114 \mathrm{~cm})$ (Povše, 1894). Razlike lahko pojasnimo tudi z boljšimi rejskimi in krmnimi pogoji reje v sedanjem času. Ferčej (1947) je izmeril telesne mere kravam planinske in ravninske »zvrsti« gorenjskega pincgavca. Prvesnice v cikastem tipu v sedanji populaciji so v vihru višje od krav planinske "Zvrsti« $(119,5 \mathrm{~cm})$. Krave ravninske »zvrsti« gorenjskega pincgavca pa so bile v vihru visoke $123,8 \mathrm{~cm}$, kar je več kot pri sedanjih prvesnicah v cikastem tipu $(121,77 \pm 3,78$ $\mathrm{cm})$ in manj kot pri prvesnicah $\mathrm{v}$ delnem cikastem tipu $(126,22 \pm 4,64 \mathrm{~cm})$. Glede na standardni odklon lahko zaključimo, da so prvesnice $\mathrm{v}$ cikastem in delnem cikastem tipu v sedanji populaciji po velikosti podobne populaciji krav gorenjskega pincgavskega goveda iz leta 1947.

Razliko med povprečnimi vrednostmi pri merjenih lastnostih pri prvesnicah vseh treh tipov lahko pojasnimo $\mathrm{z}$ oplemenjevanjem cikastega goveda s pincgavskim in $\mathrm{s}$ pretapljanjem $\mathrm{z}$ lisastim govedom $\mathrm{v}$ preteklosti. Pincgavsko in lisasto govedo imata večji telesni okvir, zato so živali v delnem cikastem in pincgavskem tipu večjega okvira. Živali v pincgavskem tipu imajo v genotipu največkrat večji delež pincgavskega goveda, kar je bilo potrjeno tudi z genetsko karakterizacijo na osnovi genetskih mikrosatelitnih označevalcev (Simčič in sod., 2013a, Simčič in sod., 2013b) in označevalcev SNP (Simčič in sod., 2015a). Prvesnice v cikastem tipu so manjšega telesnega okvira, kar je pozitivna lastnost za pasmo, katere tehnologija reje temelji na paši na strmih alpskih pašnikih. Živali manjšega telesnega okvira imajo nižje postavljeno težišče, kar omogoča, da so bolj stabilne na strmih pašnikih. Poleg tega imajo pasme $\mathrm{z}$ manjšim okvirom tudi manjše potrebe po vzdrževalni krmi (Communod in sod., 2013).

\subsection{VIRI VARIABILNOSTI}

$\mathrm{V}$ preglednici 8 so prikazani viri variabilnosti za lastnosti zunanjosti pri prvesnicah, izračunani na osnovi modela 1.

Pri prvesnicah je bil sistematski vpliv leto ocenjevanja (preglednica 8) statistično značilen pri vseh merjenih lastnostih in tudi pri vseh posameznih ocenjevanih lastnostih za avtohtonost, z izjemo lastnosti "plemenitost glave«. Prav tako je leto ocenjevanja statistično značilno vplivalo na vse posamezne lastnosti za vime. Leto ocenjevanja je statistično značilno vplivalo na vse sestavljene lastnosti, in sicer na avtohtonost, omišičenost, telesne oblike in na vime. Starost ob ocenjevanju je pri prvesnicah statistično značilno vplivala na vse merjene lastnosti in na skoraj vse posamezne lastnosti za avtohtonost. Prav tako je starost ob ocenjevanju statistično značilno vplivala na sestavljene lastnosti avtohtonost, telesne oblike in vime. Čas po telitvi je statistično značilno vplival na tri merjene lastnosti (višina vihra, višina križa, dolžina telesa), na debelino rogov in na vime pod trebuhom ter na globino vimena. Prav tako je čas po telitvi statistično značilno vplival na sestavljene lastnosti avtohtonost, omišičenost in vime.

Največji delež variabilnosti za lastnosti zunanjosti pri prvesnicah cikastega goveda smo pojasnili pri merjenih lastnostih telesnega okvira $(0,14-0,17)$. Delež pojasnjene variabilnosti je bil pri posameznih lastnostih za avtohtonost med 0,03 in 0,07 , pri sestavljeni lastnosti za avtohtonost pa 0,12 (preglednica 8).

ICAR (ICAR, 2016) priporoča analizo lastnosti zunanjosti z modelom, kjer naj bi bili vključeni vplivi starosti, stadija laktacije in sezone. Ocenjevalci naj ne bi korigirali ocen glede na starost, stadij laktacije, sezono, očeta in tehnologijo reje v času postopka ocenjevanja, ampak morajo oceniti le biološko izraženost lastnosti. Zabeležiti bi morali še način uhlevitve (prosta reja, vezana reja, reja z izpustom) in tip tal (beton, cement, les, pesek, guma, slama, pašnik), ker bi lahko vplivali na nekatere lastnosti zunanjosti.

Tudi pri analizah variance lastnosti zunanjosti pri prvesnicah italijanskih avtohtonih pasem valdostana (Mazza in sod., 2013), rendena (Mazza in sod., 2014) in piemontese (Mantovani in sod., 2010) so vključili oba vpliva, starost ob ocenjevanju in čas po telitvi. Poleg tega so vključili še interakcijo čreda-leto-ocenjevalec. $\mathrm{Z}$ navedenim modelom so pri prvesnicah rendena pasme pojasnili tudi večji delež variabilnosti $\left(R^{2}=0,19-0,36\right)$ v primerjavi s cikastim govedom. $V$ model za analizo lastnosti zunanjosti španske pasme asturiana de los valles so vključili vplive črede, interakcijo ocenjevalec-leto-sezona, čas po telitvi in starost (Gutiérrez in Goyache, 2002). Pri prvesnicah holštajn-frizijskega goveda so v model za analizo variance ocen $\mathrm{zu}$ nanjosti vključili naslednje vplive in sicer, interakcijo čreda-sezona ocenjevanja-ocenjevalec, ocenjevalec, sezona telitve in starost ob telitvi (Němcová in sod., 2011). Pri prvesnicah ameriškega rjavega goveda so v model za analizo variance ocen zunanjosti vključili vplive kot so interakcija čreda-leto-sezona, starost ob telitvi in ocenjevalec (Samoré in sod., 2010). V našem primeru interakcij med vplivi ni bilo potrebno upoštevati, ker je ocenjevalec samo eden.

Nekateri avtorji (npr. Dal Zotto in sod., 2007, Klopčič in Hamoen, 2010) priporočajo tudi vključitev telesne kondicije $\mathrm{v}$ model kot vpliv pri analizi variance lastnosti zunanjosti. Menimo, da bi bilo potrebno ocenjevanje telesne kondicije vpeljati tudi v ocenjevanje zunanjosti prvesnic cikaste pasme. 
Preglednica 8: Viri variabilnosti za lastnosti zunanjosti pri prvesnicah cikastega goveda Table 8: Sources of variability for type traits in Cika cattle first calving cows

\begin{tabular}{|c|c|c|c|c|}
\hline \multirow[b]{2}{*}{ Lastnosti } & \multicolumn{3}{|c|}{ Viri variabilnosti ( $p$-vrednosti) } & \multirow[b]{2}{*}{$R^{2}$} \\
\hline & Leto ocenjevanja & Starost ob ocenjevanju & Čas po telitvi & \\
\hline \multicolumn{5}{|l|}{ Merjene lastnosti za telesni okvir (cm) } \\
\hline Višina vihra & $<0,001$ & $<0,001$ & $<0,001$ & 0,17 \\
\hline Višina križa & $<0,001$ & $<0,001$ & $<0,001$ & 0,15 \\
\hline Dolžina telesa & $<0,001$ & $<0,001$ & 0,023 & 0,16 \\
\hline Obseg prsi & $<0,001$ & $<0,001$ & ns & 0,14 \\
\hline \multicolumn{5}{|c|}{ Posamezne lastnosti za avtohtonost (1-9) } \\
\hline Dolžina glave & 0,003 & $<0,001$ & ns & 0,06 \\
\hline Plemenitost glave & ns & 0,009 & ns & 0,03 \\
\hline Izraženost oči & $<0,001$ & ns & ns & 0,03 \\
\hline Debelina rogov & $<0,001$ & $<0,001$ & 0,001 & 0,07 \\
\hline Dolžina rogov & $<0,001$ & 0,003 & ns & 0,04 \\
\hline Usmerjenost rogov & 0,004 & 0,001 & ns & 0,03 \\
\hline Vrat & 0,001 & 0,011 & ns & 0,05 \\
\hline Izraženost podgrline & $<0,001$ & 0,002 & ns & 0,06 \\
\hline Pigmentacija plašča & 0,005 & ns & ns & 0,02 \\
\hline Izraženost hrbtne lise & 0,001 & ns & ns & 0,03 \\
\hline Izraženost pasov na zadnjih nogah & 0,001 & ns & ns & 0,03 \\
\hline Izraženost pasov na prednjih nogah & 0,001 & 0,021 & ns & 0,03 \\
\hline \multicolumn{5}{|c|}{ Posamezne lastnosti za telesne oblike (1-9) } \\
\hline Hrbet & ns & ns & ns & 0,01 \\
\hline Nagib križa & 0,009 & 0,001 & 0,001 & 0,03 \\
\hline Kot skočnega sklepa & ns & 0,007 & ns & 0,02 \\
\hline Izraženost skočnega sklepa & $<0,001$ & $<0,001$ & ns & 0,08 \\
\hline Biclji & ns & 0,006 & ns & 0,02 \\
\hline Parklji & $<0,001$ & ns & ns & 0,04 \\
\hline \multicolumn{5}{|l|}{ Posamezne lastnosti za vime (1-9) } \\
\hline Vime pod trebuhom & $<0,001$ & ns & $<0,001$ & 0,09 \\
\hline Globina vimena & $<0,001$ & 0,021 & 0,001 & 0,09 \\
\hline Debelina prednjih seskov & $<0,001$ & 0,034 & ns & 0,04 \\
\hline Dolžina prednjih seskov & $<0,001$ & 0,002 & ns & 0,06 \\
\hline \multicolumn{5}{|l|}{ Sestavljene lastnosti (1-9) } \\
\hline Avtohtonost & $<0,001$ & $<0,001$ & 0,043 & 0,12 \\
\hline Omišičenost & 0,001 & ns & 0,050 & 0,03 \\
\hline Telesne oblike & $<0,001$ & 0,001 & ns & 0,05 \\
\hline Vime & $<0,001$ & 0,014 & $<0,001$ & 0,09 \\
\hline
\end{tabular}

$R^{2}$ - koeficient determinacije, ns - neznačilen vpliv $(p>0,05)$ 


\section{SKLEPI}

Razvrščanje živali v tip poteka na osnovi ocene za sestavljeno lastnost za avtohtonost in se izvede takoj po ocenjevanju, kar onemogoča, da bi upoštevali morebitne vplive okolja. Ugotovili smo, da na lastnosti zunanjosti in posledično na razvrstitev prvesnic $\mathrm{v}$ tip pomembneje vplivajo najmanj naslednji dejavniki: leto ocenjevanja, starost živali ob ocenjevanju in stadij laktacije. Razvrstitev živali v ustrezen tip bi bilo zaradi tega potrebno opraviti po izvrednotenju ocen in izključitvi vplivov okolja. S tem bi dobili bolj pravilne razvrstitve živali v tip. Plemenske vrednosti bi lahko bolje služile kot osnova za selekcijo, saj predstavljajo večjo variabilnost kot delitev živali na tri tipe. Predlagamo, da bi ob ocenjevanju zunanjosti v bodoče upoštevali tudi telesno kondicijo živali. Hkrati bi bilo smiselno zbirati tudi informacije o sistemih reje in načinu uhlevitve.

\section{$5 \quad$ VIRI}

Communod, R., Guida, S., Vigo, D., Beretti, V., Munari, E., Colombani, C., ... Sabbioni, A. (2013). Body measures and milk production, milk fat globules granulometry and milk fatty acid content in Cabanina cattle breed. Italian Journal of Animal Science, 12(1), e18. doi:10.4081/ijas.2013.e18

Dal Zotto R., De Marchi M., Dalvit C., Cassandro M., Gallo, L., Carnier, P., \& Bittante, G. (2007). Heritabilities and genetic correlations of body condition score and calving interval with yield, somatic cell score, and linear type traits in Brown Swiss cattle. Journal of Dairy Science, 90, 5737-5743. doi:10.3168/jds.2007-0280

de Haas, Y., Janss, L. L. G., \& Kadarmideen, H. N. (2007). Genetic and phenotypic parameters for conformation and yield traits in three Swiss dairy cattle breeds. Journal of Animal Breeding and Genetics, 124, 12-19. doi:10.1111/j.14390388.2007.00630.x

Ferčej, J. (1947). Gorenjsko pincgavsko govedo. Stočarstvo, 1(6), 246-254.

Forabosco, F., Groen, A. F., Bozzi, R., Van Arendonk, J. A. M., Filippini, F., Boettcher, P., \& Bijma, P. (2004). Phenotypic relationships between longevity, type traits, and production in Chianina beef cattle. Journal of Animal Science, 82, 1572-1580.

Gutiérrez, J. P., \& Goyache, F. (2002). Estimation of genetic parameters of type traits in Asturiana de los Valles beef cattle breed. Journal of Animal Breeding and Genetics, 119, 93-100. doi:10.1046/j.1439-0388.2002.00324.x

International Committee for Animal Recording - ICAR. (2016). International agreement of recording practices. ICAR Recording Guidelines. Retrieved from http://www.icar.org/wp-content/uploads/2016/03/Guidelines-Edition-2016.pdf

Klopčič, M., Hamoen, A. (2010). Linearno ocenjevanje krav črno-bele pasme. Domžale: Biotehniška fakulteta, Oddelek za zootehniko.

Logar, B., Podgoršek, P., Jeretina, J., Ivanović, B., Perpar, T. (2005). Online-available milk-recording data for efficient support of farm management. V A. Kuipers, M. Klopcic, \& C. Thomas (ur.), Knowledge transfer in cattle husbandry (pp. 227-230). doi:10.3920/978-90-8686-547-5

Mantovani, R., Cassandro, M., Contiero, B., Albera, A., \& Bittante, G. (2010). Genetic evaluation of type traits in hypertrophic Piemontese cows. Journal of Animal Science, 88, 3504-3512. doi:10.2527/jas.2009-2667

Mazza, S., Guzzo, N., Sartori, C., Berry, D. E., \& Mantovani, R. (2014). Genetic parameters for linear type traits in the Rendena dual-purpose breed. Journal of Animal Breeding and Genetics, 131(1), 27-35. doi:10.1111/jbg.12049

Mazza, S, Sartori, C., Berry, D., \& Mantovani, R. (2013). Factors affecting linear type traits of Valdostana cattle. Agriculturae Conspectus Scientificus, 78(3), 207-211.

Navodila za presojo barvnih znakov cikastega goveda. (1935). Službeni list kraljevske banske uprave dravske banovine, 6(28), 212-213.

Němcová, E., Štrípková, M., \& Zavadilová, L. (2011). Genetic parameters for linear type traits in Czech Holstein cattle. Czech Journal of Animal Science, 56(4), 157-162.

Sadar, M., Jenko, J., Jeretina, J., Logar, B., Opara, A., Perpar, T., Podgoršek, P. (2016). Rezultati kontrole prireje mleka in mesa. Ljubljana: Kmetijski inštitut Slovenije.

Samoré, A., Rizzi, R., Rossoni, A., \& Bagnato, A. (2010). Genetic parameters for functional longevity, type traits, somatic cell scores, milk flow and production in the Italian Brown Swiss. Italian Journal of Animal Science, 9, 145-152. doi:10.4081/ ijas.2010.e28

SAS Institute Inc. (2001). The SAS System for Windows, Release 8.02. Cary, NC: SAS Institute Inc.

Simčič, M., Gorjanc, G., Čepon, M., Dovč, P., \& Kompan, D. (2013a). Genetske značilnosti populacije cikastega goveda v Sloveniji. Kmetovalec, 5, 16-18.

Simčič, M., Lenstra, J. A., Baumung, R., Dovč, P., Čepon, M., \& Kompan, D. (2013b). On the origin of Slovenian Cika cattle. Journal of Animal Breeding and Genetics, 130, 487-495. doi:10.1111/jbg.12034

Simčič, M., Smetko, A., Sölkner, J., Seichter, D., Gorjanc, G., Kompan, D., \& Medugorac, I. (2015a). Recovery of native genetic background in admixed populations using haplotypes, phenotypes, and pedigree information - using Cika cattle as a case breed. PloS ONE, 10(4), e0123253. doi:10.1371/journal.pone. 0123253

Simčič, M., Štepec, M., Logar, B., \& Potočnik, K. (2015b). Analiza lastnosti zunanjosti pri plemenskih bikih cikastega goveda. Acta agriculturae Slovenica, 106(2), 103-112. doi:10.14720/ aas.2015.106.2.6

Špehar, M., Štepec, M., \& Potočnik, K. (2012). Variance components estimation for type traits in Slovenian Brown Swiss cattle. Acta agriculturae Slovenica, 100(2), 107-115.

Žan, M., Čepon, M., Kompan, D. (2005). Rejski program za cikasto govedo: dopolnjen v skladu s pripombami MKGP $z$ dne 05. 01. 2005. Mengeš: Govedorejska zadruga.

Žan Lotrič, M., Čepon, M., Kompan, D, Klinkon, Z., Rokavec, R., Jeretina, J., ... Burja, A. (2010). Rejski program za cikasto govedo: dopolnjen $v$ skladu s pripombami MKGP $z$ dne 27. 09. 2010. Medvode: Združenje rejcev avtohtonega cikastega goveda v Sloveniji. 